\title{
Comparative Review on National Strategies in the Prevention of Domestic Violence
}

\author{
Ko Ling Chan ${ }^{*}$
}

Department of Social Work and Social Administration, The University of Hong Kong, Pokfulam, Hong Kong

\begin{abstract}
The objective of this study is to identify the essential elements of national policies that contribute to the prevention of domestic violence with reference to the selected eight countries. National policies and strategies to combat domestic violence are reviewed, and the central mechanisms in each country that implement policy and coordinate service delivery are identified. The United States adopts a national legislation approach to criminalize domestic violence. Canada is committed to criminalizing domestic violence through a coordinated criminal justice response. The UK and Australian government prefer a partnership approach to mobilize community resources. New Zealand and Singapore aim at strengthening and supporting families. The experiences in the Mainland China and Taiwan demonstrate that the making of national legislation and policy are acceptable to change harmful practices of traditional Chinese families. Family is no longer a private domain and violence in families would be stopped by public intervention. The study provides information about the national policies for preventing domestic violence.
\end{abstract}

Keywords: Domestic violence, prevention, policy, comparative.

\section{INTRODUCTION}

The public health approach [1] in the prevention of family violence $[2,3]$ stipulates that the health of individuals and groups depends upon social policies and programmes, and coordinated national, regional and community efforts in the building of healthy communities. National strategies in violence prevention vary between countries and within a country.

In view of the increasing global concern of family violence, in particular, child maltreatment [4] and intimate partner violence [5], it is of high value to review national policies and strategies in combating family violence. The objective of this study is to identify the essential elements of national policies that contribute to the prevention of domestic violence with reference to the selected eight countries, including the USA, Canada, the UK, Australia, New Zealand, Singapore, Mainland China and Taiwan. Domestic violence includes all forms of violence committed by any member of a family against another member of the same family. To maintain the focus of the review, partner violence, violence against children and violence against elderly people are addressed.

\section{MATERIALS AND METHODOLOGY}

Eight countries were included in the review. The selection criteria were mainly based on the diversity of countries and the information available in literature and official websites. The references found were based on Web pages of the governments, related community groups or

\footnotetext{
*Address correspondence to this author at the Department of Social Work and Social Administration, The University of Hong Kong, Pokfulam, Hong Kong; Tel: 852-2859 2077; Fax: 852-2858 7604;

E-mail: eklchan@hkucc.hku.hk
}

academia of these countries. The literature review took place was from January to March, 2007. The review started by studying national policy and strategies in combating domestic violence. Research questions include what policy and strategies are the countries under review undertaking to prevent domestic violence? What is the central mechanism in each country that implements policy and coordinate services?

\section{RESULTS}

USA - Criminalization of Domestic Violence: National Legislation Approach

\section{National Policy}

In the United States, the key national policy of violence prevention is to criminalize abuse of children, of domestic partners and of the elderly by mandating members of the medical and social service professions to report suspected cases of abuse and by prosecuting the perpetrators of acts identified as abusive [6]. National strategies to combat violence are mainly created through national legislation.

Child protective services are guided by the federal Child Abuse Prevention and Treatment Act (CAPTA) that mandates the reporting of abuse, funds child protective services and gives officials power to remove children from violent homes. The federal Older Americans Act defines elderly abuse and allocates federal funds for a National Center on Elder Abuse. Strategies to combat violence against women are outlined in the Violence Against Women Act (VAWA) of 1994 - the nation's first comprehensive federal response to the violence that plagues families and communities. Congress reauthorized and expanded the law in 2000 and again in 2005.

VAWA (1994), as a vital first step in the nation's efforts to treat domestic violence as a serious problem, created new 
penalties for gender-related violence and new grant programmes encouraging states to address domestic violence and sexual assault. These include law enforcement and prosecution grants, grants to encourage arrest, rural domestic violence and child abuse enforcement grants, the National Domestic Violence Hotline and grants to battered women's shelters. The reauthorization of VAWA in 2000 continued this work by adding civil legal assistance, transitional housing and supervised visitation centres; by strengthening existing legislation through allowing Grants to Encourage Arrest; and by creating new services for immigrant, rural, disabled and older women who are victims of violence. VAWA 2005 also emphasized prevention by targeting resources at children and youth who have been exposed to violence, and engaging men as allies in this work. It also made amendments to criminal and immigration law, consolidated major law enforcement grant programmes and authorized appropriations for the Department of Justice.

\section{Central Mechanism for Handling Domestic Violence}

The funding levels for programmes that benefit battered women and their children are determined by the House and Senate Appropriations Committees. Two subcommittees have been set up in the House and Senate to oversee VAWA programmes that are run by the Department of Health and Human Services and the Department of Justice. These committees draft appropriations legislation in response to the President's budget request, which represents the Administration's spending priorities in a given year.

The coordination of services related to violence against women is mainly carried out through the National Advisory Council on Violence Against Women, which was created in 1995 by the above two departments [7]. The Council's work mainly involves making suggestions about policies and practices to end sexual and domestic violence against women.

Services related to violence against women and children are mainly coordinated by the Department of Health and Human Services under the authorization of VAWA (2005). They include the making of the Family Violence Prevention and Services Act, a National Domestic Violence Hotline, transitional housing, rape prevention and education grant programme, and Centers for Disease Control and Prevention Community Initiatives. The Department of Justice provides Violence Against Women Funding that includes civil legal assistance for victims; supervised visitation centres; courtappointed special advocates; judicial training; televised testimony; grants to encourage arrests and reduce stalker and domestic violence; and grants to end violence against women with disabilities, sexual assault against older or disabled individuals, rural domestic violence and child victimization, as well as campus violence.

\section{Effectiveness of the Antiviolence Policy}

The US government is committed to the criminalization of domestic violence. Handling domestic violence is not solely a welfare issue. The criminal justice systems are actively coordinating the improvement of policy and practice. The US Attorney General's Task Force on Family Violence [8] has acknowledged that judges and sentences could strongly reinforce the message that violence is a serious criminal matter for which the abuser should be held accountable. If judges fail to handle family violence with an appropriate level of concern, then the crime becomes trivialized and victims will receive no real protection or justice.

There is plenty of evidence that the violence prevention programmes directed by VAWA are effective. A decline in domestic violence has been reported by the Justice Department's Bureau of Justice Statistics (BJS), which highlights the effectiveness of violence prevention programmes. In 1993, the rate of nonfatal intimate partner violence was 5.8 victimizations per 1,000 US residents 12 years old and older. By 2004, this rate had fallen to 2.6 victimizations per 1,000 individuals [9].

\section{Canada - A Coordinated Criminal Justice Response \\ National Policy}

In Canada, a comprehensive federal approach is adopted to handle domestic violence. As in the United States, Canada is committed to criminalizing domestic violence. The Department of Justice has made efforts to strengthen the criminal justice system when dealing with spousal abuse cases. Suggested measures include establishing and enforcing mandatory reporting, charging and prosecution policies; setting up domestic violence courts; and introducing protective measures for victims and mandated treatment for abusers. The Department also recommends further efforts to support victims, deal with the high attrition rate of spousal violence cases in court, reduce under-reporting and better train criminal justice personnel [10].

Mandatory reporting, charging and prosecution policies were developed after the Minister of Justice and Solicitor General issued a public statement on the investigation and prosecution of spousal violence in 1983 [11]. These measures aimed to remove victims from the responsibility to initiate criminal charges and ensure that police investigators gave priority to arrest cases that involved spousal violence. The Mandatory Charge Policy was first enacted in Yukon in 1983.

Family violence courts were established in Winnipeg in 1990 and Ontario in 1997 [12,13]. Since 1990, the Winnipeg Family Violence Court has handled cases of spousal, child and elderly abuse in Winnipeg. It was the first jurisdiction in Canada to develop a specialized Family Violence Court for family violence cases. The goals were to achieve expeditious court processing, rigorous prosecution and more appropriate sentencing than nonspecialized courts [12]. Five major strategies were used to achieve these goals: (a) a proarrest policy known as the Zero Tolerance Policy; (b) a women's advocacy and child victim witness programme for victims of family violence; (c) a specialized prosecutorial unit of 11 crown attorneys in Winnipeg; (d) specially designated court rooms and dockets for intakes, screening courts and trials; and (e) a special unit in the probation office to deliver courtmandated treatment programmes. The effectiveness of these strategies were clear: during the first two years that the Court was operating (1990-1992), there was a $150 \%$ increase in spousal abuse charges, from 1.302 to 3.316 ; an $89 \%$ increase in child abuse charges, from 371 to 702 ; and a $138 \%$ increase in elderly abuse charges, from 26 to 62 . About $53 \%$ of all persons sentenced in the Family Violence Court were 
referred to court-mandated treatment. After seven years of operation, about $62 \%$ of all convicted offenders had supervised probation as one of their sentencing outcomes. About $68 \%$ of those who received a supervised probation sentence were required to join batterers' treatment groups [13].

In 1997, a Domestic Violence Court was established in Toronto with the aim to provide better support to victims of domestic abuse throughout the criminal justice process, to prosecute domestic violence cases more effectively and to hold offenders accountable for their behaviour if they were found guilty of a domestic violence-related offence.

The Coordinated Prosecution Component of the Court sought to ensure that domestic violence cases were prosecuted more effectively [14]. The ability to proceed with a prosecution had previously depended largely on the victim's testimony. Because of fear or intimidation, victims often recanted their original statements to the police or refused to testify. This often necessitated the withdrawal of charges by the prosecution, because without the victim's testimony, there might be no reasonable prospect of conviction. The specially trained domestic violence crown prosecutors relied on 'enhanced evidence' to proceed with the prosecution, particularly if the victim recanted the original statement made to the police. The evidence could include 911 tapes, medical reports, photographs of injuries, interviews with family members and neighbours, and audio- and/or videotaped victim statements. The Police would lay charges where there were reasonable grounds to believe that the offender had breached the conditions of bail or probation. These proactive prosecution practices helped to reduce the burden of victims and thus create a strong message for the public that the criminal justice system is committed to upholding a zero tolerance of violence policy.

Related legislative reforms were enacted to improve the criminal justice legal framework to address family violence in Canada [10]. These included increasing the maximum penalty for criminal harassment, creating a new antistalking offence of criminal harassment, facilitating victims' participation in the criminal justice process by banning the publication of their identities and making the application of peace bonds (protective orders) easier, and allowing the police and others to apply on behalf of a person at risk of harm for a peace bond.

\section{Central Mechanism for Handling Domestic Violence}

The Family Violence Initiative (FVI) coordinates the federal government and 15 partner departments [15]. The FVI provides policy and legal advice on how to improve the criminal justice system's response to family violence. The FVI promotes public awareness of the risk factors of family violence and the need for public involvement in responding to it; strengthens the criminal justice, housing and health systems' ability to respond; and supports data collection, research and evaluation efforts to identify effective intervenetions. Under the coordination of the FVI, the issue of family violence has been integrated into an ongoing programme across many government departments that supports a common vision and a coordinated approach.

Provincial government is also committed to violence prevention. In Manitoba, for example, the Family Violence Prevention Programme provides funding to specialized services for women, their children and men caught in the cycle of family violence. These services are delivered by 34 agencies in the community across the province.

\section{UK - A Coordinated Community Response}

\section{National Policy}

The UK government adopts a partnership approach to domestic violence prevention through a coordinated community response that involves the public and voluntary sectors, the justice system, and national and local agencies. The collaboration of multi-agencies is monitored through planned policy, strategies, measures and actions taken by the community, including health and social services, and the criminal justice system (including the police, the Crown Prosecution Service, the courts and the probation service).

The commitments of the government and the strategies to tackle domestic violence were spelled out clearly through policy papers issued by the Home Office in 1995 [16] and the Cabinet Office in 1999 [17]. These papers outline the roles and responsibilities of all relevant government departments and encourage service providers, both in government and voluntary sectors, to work together in partnership.

In 2003, a number of legal remedies were adopted in the criminal justice system to enhance its effectiveness in providing safety for victims within a multiagency framework that works with victims, perpetrators and their children. 'Safety and Justice: The Government's Proposals on Domestic Violence' [18,19] addressed issues of prevention, protection and support. The strategies included are described below.

a) Prevention: working to prevent it happening in the first place, and working with victims and offenders to prevent it recurring. This involves: (i) educating people about domestic violence, and changing attitudes that tolerate it; (ii) helping agencies and professionals to address risk factors and identify victims as early as possible; (iii) providing information to victims to help them gain access to support services and legal protecttion; and (iv) offering programmes run by the prison and probation services that aim to prevent domestic violence offenders from reoffending.

b) Protection and justice: increased legal protection for victims and their families. This involves: (i) extending the availability of nonmolestation and occupation orders under the Family Law Act 1996; (ii) criminalizing the breach of such orders; (iii) increasing the protection courts provide to victims of and witnesses to domestic violence; (iv) extending the availability of restraining orders under the Protection from Harassment Act 1997 to cover all violent offences; (v) making common assault an arrestable offence; (vi) establishing a register of civil orders; (vii) establishing a register of domestic violence offenders; (viii) referring sentencing in domestic violence cases to the Sentencing Advisory Panel; (xi) improving the way the law on homicide operates in domestic violence cases; (x) establishing multiagency reviews after domestic violence homicides to learn lessons about how agencies might have prevented the 
death; and (xi) improving liaison between the operation of the civil and criminal courts.

c) Support for victims to help them rebuild their lives. This involves: (i) providing safe accommodation and housing; (ii) providing benefits; (iii) introducing measures to support victims; and (iv) providing support and counselling services for children affected by domestic violence.

In 2005, the Home Office published its National Report on Domestic Violence [20], which reviewed the progress that had been made in implementing the proposals outlined in 'Safety and Justice' and highlighted new commitments that form the 'next steps' in delivering services and support to victims of domestic violence. These include an outline of a working document called the National Domestic Violence Delivery Plan.

\section{Central Mechanism for Handling Domestic Violence}

The Home Office is the lead agency for interdepartmental initiatives on domestic violence policy. The central coordinating mechanism is the Interdepartmental Group on Violence Against Women and Domestic Violence, which is chaired and serviced by the Home Office. The Group is responsible for taking forward initiatives on domestic violence within the Home Office and for coordinating actions on domestic violence and violence against women across government departments.

In summary, the UK has adopted a comprehensive and coordinated criminal justice response to domestic violence prevention [21]. All criminal justice interventions in the UK have been found to have positive effects on the behaviour of men who were convicted of violence against their female partners [22]. The provision of community-based and prisonbased programmes ensures that perpetrators receive education aimed at changing their violent behaviour. A criminal justice system provides a strong monitoring authority that can help to stop domestic violence.

\section{Australia - A Partnership Approach \\ National Policy}

In Australia, domestic violence is considered a form of gendered violence, which is an abuse of power [23]. The Australian government recognizes that government cannot work alone to stop domestic violence; it needs to form partnerships. In November 1997, the Heads of Government endorsed Partnerships Against Domestic Violence (Partnerships), an initiative between the Commonwealth, the States and the Territories to work together towards the common goal of preventing domestic violence across Australia.

Partnerships is concerned with building a strategic collaboration between the Commonwealth, States and Territories to test new ways of doing things, to enhance and share knowledge, and to develop and document good practice in preventing and responding to domestic violence [24]. The project is implemented by the Partnerships Taskforce in Australia, which is chaired by the Commonwealth Office in Australia. As in the UK, interagency coordinated approaches, based on a multidisciplinary approach, offer an opportunity for the development of a consistent approach to dealing with domestic violence within a specific location. A range of coordinated models have emerged that vary in size and scope, with local conditions such as legislation and available services being important variables in their development [24].

In 2005, the Partnerships programme has been replaced by the Women's National Safety Agenda administered by the Australian Government Office for Women (OfW), which is a policy advisory unit and a division of the Department of Families, Community Services and Indigenous Affairs in Australia. The Office provides high-level advice to the Prime Minister and the Minister Assisting the Prime Minister for Women's Issues who is responsible for advising the Prime Minister on women's issues [25]. It administers programmes, including programmes to combat domestic violence and sexual assault; advises on legislative issues relating to women; provides the principal focus on consultation between the women's sector and government; and represents government at national and international forums on women's issues [26].

In 2005, the Australian government reiterated its commitment to eliminate domestic violence and sexual assault in the Australian Community - Women's Safety Agenda. The Women's Safety Agenda addresses four major themes, prevention, health, justice and services, and aims to decrease the impacts of domestic violence and sexual assault upon the community by building on the achievements of the Partnerships initiative and the National Initiative to Combat Sexual Assault, by increasing the focus on preventing violence and providing early intervention, and by enhancing support for those affected by violence. There are several important strategies, including the following: (a) The National Campaign, called Violence Against Women. Australia Says No, has been developed by the Australian government to deliver a strong message that violence against women is totally unacceptable; (b) The Domestic and Family Violence and Sexual Assault Initiative is an Australian Government Office for Women funding programme that aims to reduce the impact of domestic violence and sexual assault on the Australian community, and to prevent it; (c) Continued funding is provided for the Australian Domestic and Family Violence Clearinghouse and the Australian Centre for the Study of Sexual Assault, which provide central points for the collection and dissemination of Australian domestic and family violence and sexual assault policy, practice and research. Funding is also provided for research and pilot projects concerning domestic violence and sexual assault in the Australian community; (d) Training is provided for nurses in regional and rural areas and for the criminal justice sector on sexual assault; (e) A National Helpline has been set up to provide immediate counselling, crisis referral and call transfer services to support the Violence Against Women campaign. The Helpline is in operation 24 hours a day, 7 days a week. A Mensline service is also provided by counsellors.

With regard to child protection, it is stated under the Australian Constitution that child protection intervention services are the responsibility of the community services department in each state and territory. The Minister for Families, Community Services and Indigenous Affairs is 
responsible for the national strategies for preventing child abuse. The Australian government, through the Department of Families, Community Services and Indigenous Affairs (FaCSIA), promotes best practice nationally in the areas of child abuse prevention and early intervention and prevention. FaCSIA funds the National Child Protection Clearinghouse, which is based in the Australian Institute of Family Studies, to disseminate information on child protection activities and research to professionals and organisations in this field.

In 2006, the Intergovernmental Summit on Violence and Child Abuse in Indigenous Communities, involving Ministers from the Australian Government and all States and Territories, agreed that the levels of violence and child abuse in indigenous communities warrants a comprehensive national response. All governments agree that preventing family violence and child abuse in indigenous families is a priority that requires a national effort. Jurisdictions work cooperatively to improve how they engage with each other and work in partnership with indigenous communities to tackle this issue under a new National Framework on Indigenous Family Violence and Child Protection drawn up by the Council of Australian Governments (COAG) in June 2004. The safety of victims; partnerships to prevent family violence and child abuse; and the building of strong, resilient families are emphasized. It was agreed that a comprehensive response to the issue of violence and child abuse requires a coordinated criminal justice system, and sound community and corporate governance.

\section{Central Mechanism for Handling Domestic Violence}

At the ministerial level, the Minister for Families, Community Services and Indigenous Affairs is responsible for national strategies for preventing child abuse, while the Minister Assisting the Prime Minister for Women's Issues provides advice to the Prime Minister. The Intergovernmental Summit on Violence and Child Abuse in Indigenous Communities makes national policy to guide the handling of domestic violence among the government and all states and territories. The Department of Families, Community Services and Indigenous Affairs (FaCSIA) coordinates and funds services related to the intervention and prevention of domestic violence.

\section{New Zealand - Strengthening Families \\ National Policy}

According to the national policy of New Zealand, domestic violence is a serious social problem that affects public health and has negative social and economic costs to society. The New Zealand government sees domestic violence as an abuse of human rights. It is a public issue rather than a private one [27]. The national policy for tackling domestic violence is based on the New Zealand Domestic Violence (DV) Act 1995, which guides the government's practice of strategies to combat domestic violence. The Domestic Violence Rules thus give an overview of how the DV Act should be implemented.

In March 2002, the Ministry of Social Development (MSD) launched Te Rito, the New Zealand family violence prevention strategy. Te Rito is a collaborative approach between government and NGOs. It sets out the government's key objectives, guiding principles and a five-year implementation plan to work towards achieving the vision of families living free from violence. The strategy is a product of the positive working relationship between government and nongovernment agencies, and represents a collaborative effort towards preventing violence in families/whanau [27].

The family violence prevention programmes set out by Te Rito mainly include the family violence intervention programme, the community action fund and toolkit, prevention services for children and young people who witness family violence, elderly abuse and neglect, family violence funding coordination networks, strong pacific families and the New Zealand family violence clearinghouse. The government places strong emphasis on the strengthening of families as a means of prevention. In July 2004, the MSD established the Families Commission under the Families Commission Act 2003. The purpose of the Commission is to advocate for the needs and interests of all families to the government and the wider community. The key functions are: (a) increasing awareness and understanding of the issues that families face and encouraging public debate on familyrelated matters; (b) looking at current research on families, identifying knowledge gaps, and conducting new and innovative research; (c) publishing research findings and other information we gather; (d) looking at the impact of current and proposed government policies on families; (e) contributing to the development of new policies that are supportive of families; and (f) providing advice about families to government agencies and other organisations [28].

\section{Central Mechanism for Handling Domestic Violence}

The central coordinating mechanism in the prevention of family violence is the Ministry of Social Development [29], which is one of New Zealand's largest government departments that provides the government with advice on strategic social policy, sectoral policy, and social research and evaluation in the areas of income support, children, youth and the family, as well as the community.

The Te Rito National Executive, a group of representtatives from government and nongovernment agencies, was set up in June 2002 to monitor the implementation of Te Rito. A key role of the National Executive is to ensure ongoing commitment to the principles and goals of Te Rito across the family violence prevention sector. The Taskforce for Action on Violence Within Families was established in June 2005 to advise the Family Violence Ministerial Team on how to make improvements to the way family violence is addressed, and to eliminate family violence in New Zealand.

\section{Singapore - Supporting and Protecting the Family \\ National Policy}

Singapore mainly adopts a policy of supporting and protecting the family. The National Family Council, formed on 1 May 2006, is an advisory and consultative body for family-related policies, issues and programmes. The Council promotes the building of resilient families in Singapore; consults the public and provides feedback to the government on family policies, family education programmes, research and services; engages key stakeholders in the people, private and public sectors to create a conducive environment for 
families; and provides inputs on resource allocation to enhance the capacity and capability of the family service sector [30].

The aim of the Family Policy is to imbue Singaporeans with profamily values and encourage family formation and bonding; to equip families with knowledge and skills to create and manage a quality family life; to create a profamily environment with strong community support for families through family services such as childcare and elderly care; and to encourage women's participation in and contribution to the family and the community.

A Mandatory Counselling Programme helps perpetrators find ways of dealing with stress, anger or conflict that do not involve being violent, and provides help and support to victims of violence who need safety and protection from further hurt. A Counselling Order (under the Section 65 of the Women's Charter) is usually made when the Family Court issues a Personal Protection Order.

\section{Central Mechanism for Handling Domestic Violence}

Family protection is one of the key functions of the Ministry of Community Development, Youth and Sports (MCYS). Policy is mainly guided by the Women's Charter (Amendment) Bill 1996, which defines family violence. The National Family Violence Networking System initiated by MCYS is a collaboration between government and nongovernment agencies that seeks to deal with family violence cases, increase public awareness of the issue of family violence and encourage community participation in the prevention of family violence.

\section{Mainland China - The Making of Social Policy National Policy}

The Chinese government has been one of the state parties of the Convention on the Elimination of All Forms of Discrimination Against Women (CEDAW) since 1980. The Chinese government adopted the Beijing Declaration and Platform for Action at the Fourth World Conference on Women, held in September 1995. Former President Jiang pointed out in his speech at the Conference that the notion of equality between men and women should be adopted as a basic state policy in promoting the development of society.

Article 43 of the Marriage Law of the People's Republic of China states that the victim of domestic violence shall have the right to make a request and the public security organ shall stop the violence. The government's commitment to stop all forms of domestic violence is also stated in the Law of the People's Republic of China on the Protection of Rights and Interests of Women. The Programme for the Development of Chinese Women states that equality between men and women, and stopping domestic violence should be adopted as basic state policy. In the Programme for the Development of Chinese Women, the government stresses the importance of the development of women and children, and makes a solemn commitment to the international community. This programme combines short- and long-term objectives to promote women, and presents a wide range of prospects for their development in economics, politics, education, health care, legal aid and the environment.
There are more and more services in Mainland China aimed to stop domestic violence, including hotline and counselling services, shelters for battered women, and educational programmes and campaigns such as the 'zero domestic violence community' campaign run by the AllWomen's Federation in 2005. The local governments are also active in combating domestic violence, such as with the setting up of the Circuit Court for Women in Fuzhou. The purpose of this, the first circuit court in Fuzhou, is to safeguard women's rights and interests. It comprises eight judges, some of whom are women, as well as special jurors, including the director of the Minhou women's federation and the heads of women's federations from 16 townships. This special court serves the needs of women suffering from domestic violence and simplifies the legal procedures involved in domestic violence cases.

\section{Central Mechanism for Handling Domestic Violence}

The National Working Committee on Children and Women Under the State Council (NWCCW) is a coordinateing organization that is responsible for giving advice to government departments on the prevention of domestic violence. The All-China Women's Federation (ACWF) is the largest NGO that aims to improve the status of women in China. Its basic function is to stand up for women, protect their rights and interests, and promote equality between the sexes. It promotes the ending of domestic violence as well as the protection of women and children at national and local levels through its local federations in all provinces.

Taiwan - Legislation and Family Policy

\section{National Policy}

The Ministry of the Interior established a Sexual Assault Prevention Commission in 1997 and a Domestic Violence Prevention Commission in 1998. In July 2002, both commissions were merged into a Domestic Violence and Sexual Assault Prevention Commission. In 2004, a Family Policy was passed. The policy aimed to 'terminate domestic violence, provide domestic violence victims and witnesses with related support measures and strengthen inflectors' treatment service to achieve family reconstruction' [31].

The protection of women and children from domestic violence is mainly based on two pieces of legislation, the Domestic Violence Prevention Act and the Sexual Assault Crime Prevention Act. These acts provide protection through the provision of protective orders, probation orders, modifying visitation orders after domestic violence has been reported and court-mandated intervention programmes against batterers.

A number of prevention strategies have been implemented, such as a national 24-hour helpline, work skills training for victims, counselling of children who witness domestic violence, training of prevention and protection network workers, education through the mass media, the conducting of research and so on [32].

\section{Central Mechanism for Handling Domestic Violence}

The Ministry of the Interior is in charge of the administration of national social welfare matters while the Department of Social Affairs is responsible for the planning, 
implementation and administration of social welfare, as well as education in social welfare. It is also in charge of public assistance, social insurance and civil organizations. In November of 1999, a Child Welfare Bureau was set up, under the Ministry of the Interior, to deal with child welfare matters.

At the central government level, the Domestic Violence Prevention Act (the Act) is used by the Domestic Violence Control and Prevention Committee, under the Ministry of the Interior, which performs the following functions: (1) It develops policies and regulations; (2) it coordinates, monitors and evaluates the performance of domestic violence control and prevention legislation; (3) it promotes the efficiency and competence of the services provided by agencies that educate the general public; (4) it coordinates the provision of protection and treatment programmes; (5) it supports both public and private institutions in creating domestic violence management procedures and promoting domestic violence control and prevention education programs; (6) it sponsors the creation of an integrated database of domestic violence offenders that can be referred to by judges, prosecutors, policemen, medical personnel and other governmental agencies; (7) it monitors the retention of strict confidentiality regarding the identity of victims; (8) it provides the relevant support for local government.

At the local level, local government bodies create Domestic Violence Prevention Committees and maintain a Domestic Violence Prevention Centre, coordinating efforts by the police administration, education, health, social administration, household administration and judicial units concerned with protecting the interests of domestic violence victims and preventing domestic violence from occurring.

\section{DISCUSSION}

Law enforcement is a common strategy in violence prevention among the countries reviewed. It is stated in the United Nations' report World Report on Violence Against Children that although many states have laws making assault a criminal offence, "these laws are not interpreted as prohibiting all violence against children, and in many States legislation contains justifications or defences for corporal punishment." "In over 70 countries, the English commonlaw defence of 'reasonable' or 'moderate' chastisement of children has remained following periods of colonisation. In order to prohibit all corporal punishment, any such defences must be removed and prohibition of corporal punishment and other forms of cruel or degrading punishment made explicit" (p. 74) [4]. The requirement to review and revise existing laws and policy to address violence against women was spelled out by the international community [5]. A further criticism was made that weak legal frameworks contribute both directly and indirectly to family violence against children (p. 70) [4]. Specific laws are needed that criminalize domestic violence and prohibit all forms of violence against women and children, as the USA, Canada, and the UK do.

Legal and judicial reforms serve to validate the "zero tolerance" attitude of the government by criminalizing abusive behavior. It is through introducing mandatory and voluntary reporting of cases of domestic violence that the early detection of abuse is encouraged, and this in turn prevents the occurrence of serious injuries and increases the safety of victims by relieving them of the necessity to make reports. Other legal measures include the enhancement of child and victim protection services, the review of arrest and prosecution policies, the launch of court-mandated treatment for offenders, the setting up of specialized domestic violence courts, the requesting of domestic violence homicide/fatality reviews, and the launch of family justice center. Police officers, probation officers, prosecutors, and judges in the legal system are the authorized parties with the mandate to protect victims, sanction the perpetrators, and send a message to society that domestic violence is not a private matter but a priority crime arousing social concern.

Mandatory reporting policies require health and social services professions to file a report with the police when they suspect that a patient's injuries are related to domestic violence. The aim of the policy is to counteract the indifference of medical professionals toward domestic violence [33]. Reporting domestic violence cases to police is a very important step to assist in the early identification of potential risk cases, without waiting for the decision of the victims or the occurrence of a traumatic event. Critics argue that this policy deters victims from seeking medical advice. Research shows that $59 \%$ of the medical practitioners in California said that if a patient was opposed to it, they might not report the case [34]. Women's groups oppose the policy, citing reasons such as fear of retaliation by the abuser, mistrust of the legal system, fear of family separation, and preference for confidentiality and autonomy [35]. But some other studies show that $68 \%$ of physicians in the USA think that if the patients had no objection, they would report the cases.

On its own, the mandatory reporting would not be effective. The experience of Canada demonstrates that such a policy should be a part of coordinated criminal justice responses that include mandatory reporting, charging and prosecution policies, as well as an integrated family violence court.

\section{CONCLUSION}

Learning form the experiences in different countries, the establishment of a clear anti-domestic violence policy as well as the setting up of a powerful central mechanism to coordinate prevention strategies should be considered the tasks possessing the highest priority.

\section{REFERENCES}

[1] Potter LB, Rosenberg ML, Hammond WR. Suicide in youth: A public health framework. J Am Acad Child Adolesc Psychiatr 1998; 37: 484-7.

[2] Krug EG, Dahlberg LL, Mercy JA, Zwi AB, Lozano R. Eds. World report on violence and health. Geneva, World Health Organization 2002.

[3] World Health Organization. Preventing violence: A guide to implementing the recommendations of the World report on violence and health (LC/NLM classification: HV 6625). Geneva: World Health Organization 2004.

[4] Pinheiro PS. World report on violence against children. Geneva, Switzerland: United Nations Secretary-General's Study on Violence Against Children 2006.

[5] The Division for the Advancement of Women of the Department of Economic and Social Affairs of the United Nations Secretariat. In- 
depth study on all forms of violence against women: Report of the Secretary-Genera (A/61/122/Add.1). Geneva, Switzerland: United Nations, The Secretary-General's in-depth study on violence against women 2006.

[6] Hines DA, Malley-Morrison K. Family violence in the United States: Defining, understanding, and combating abuse. Thousand Oaks, CA: Sage 2005

[7] The Office on Women's Health, National Women's Health Information Center. Violence Against Women [Online]. 2003, [cited 2007]. Available from http://www.4woman.gov/violence/ legislation

[8] U.S. Attorney General's Task Force on Family Violence. Enhancing Justice Programmes. Building Partnership to End Men's Violence. Family Violence Prevention Fund [Online]. 2003, [cited 2007]. Available from http://endabuse.org/bpi/

[9] Catalano S. Intimate Partner Violence in the United States [Online]. 2007 Dec 19, [cited 2007]. Available from: http://bjs.ojp.usdoj.gov/content/pub/pdf/ipvus.pdf

[10] Department of Justice Canada. Family Violence. CA: Department of Justice [Online]. 2003, [cited 2007]. Available from: http:// canada.justice.gc.ca/en/ps/fm/familyvfs.html

[11] Roberts T. Spousal Assault and Mandatory Charging in the Yukon: Experiences, Perspectives and Alternatives. Working Document for Department of Justice, Canada, Victoria, BC: Focus Consultants 1996.

[12] Ursel EJ..The Winnipeg Family Violence Court. Service Bulletin. Statistics Canada, May 1994 [14, Issue 12. Retrieved 2007 Jan 15]. Available from: http://www.eurowrc.org/01.eurowrc/04.eurowrc en/40.en_ewrc.htm

[13] Ursel EJ. Winnipeg Family Violence Court Report. Statistics Canada. In: Family Violence Courts. Family Violence in Canada: A Statistical Profile 2000. Canada: Canadian Centre for Justice Statistics (Ottawa: Statistics Canada: Cat no. 85-224-XIE) [Online]. 2000 July, [cited 2007]. Available from: http://www. statcan.ca/english/freepub/85-224-XIE/0000085-224-XIE.pdf

[14] McCallum T. Ontario Domestic Violence Courts Initiative. In: Family Violence Courts. Family Violence in Canada: A Statistical Profile 2000. Canada: Canadian Centre for Justice Statistics (Ottawa: Statistics Canada: Cat no. 85-224-XIE) [Online]. 2000 July, [cited 2007]. Available from: http://www.statcan.ca/ english/ freepub/85-224-XIE/0000085-224-XIE.pdf

[15] Including Public Health Agency of Canada, Canada Mortgage and Housing Corporation, Department of Justice Canada, RCMP, Canadian Heritage, Status of Women Canada, Statistics Canada, Indian and Northern Affairs Canada, Health Canada, Human Resources and Social Development Canada, Citizenship and Immigration Canada, Correctional Service of Canada, Public Safety and Emergency Preparedness, Service Canada and the Department of National Defense.

[16] Home Office. Home Office circular - domestic violence. London: Home Office [Online]. 1995, [cited 2004]. Available from: http: //www.homeoffice.gov.uk/docs/hoc1900.html

[17] Cabinet Office. Living without fear: An integrated Approach to Tackling Domestic Violence [Online]. 1999, [cited 2007].
Available from: http://www.womenandequalityunit.gov.uk/archive/ living without fear/contents.htm

[18] Home Office. Safety and justice: The government's proposals on domestic violence (CM 5847). UK: The Stationery Office 2003.

[19] Home Office. Summary of responses to 'Safety and Justice: The Government's Proposals on Domestic Violence'. UK: The Stationery Office 2003.

[20] Home Office. Domestic violence: A national report. UK Government 2005.

[21] Home Office. Domestic Violence: Break the Chain - Multi-Agency Guidance for Addressing Domestic Violence. London: Home Office [Online]. 2000, [cited 2004]. Available from: http://www. homeoffice.gov.uk/docs/mag.html

[22] Dobash RP, Dobash RE, Lewis C. Research evaluation of programmes for violent men. Edinburgh: Scottish Office Central Research Unit 1996.

[23] Commonwealth Office of the Status of Women (2003). Partnership taskforce. Au: Commonwealth Office of the Status of Women [Online]. 2007 Jan 15, [cited 2007]. Available from: http://www. padv.dpmc.gov.au

[24] Partnerships Against Domestic Violence. Current perspectives on domestic violence: A review of national and international literature. Strategic Partners Pty Ltd in collaboration with the Research Centre for Gender Studies, University of South Australia 1999.

[25] Minster for the Status of Women [Online]. 2007 Jan 15, [cited 2007]. Available from: http://ofw.facsia.gov.au/minister/

[26] Office for women [Online]. 2007 Jan 15, [cited 2007]. Available from: http://ofw.facsia.gov.au

[27] Ministry of Social Development. TE RITO New Zealand Family Violence Prevention Strategy. NZ: Ministry of Social Development 2002

[28] Families Commission [Online]. 2007 Jan 15, [cited 2007]. Available from http://www.nzfamilies.org.nz/.

[29] Ministry of Social Development [Online]. 2007 Jan 15, [cited 2007]. Available from: http://www.msd.govt.nz/index.html

[30] Ministry of Community Development, Youth and Sports [Online]. 2007 Jan 15, [cited 2007]. Available from: http://app.mcys.gov.sg/ web/faml supfaml.asp

[31] Social Welfare Administration [Online]. 2007 Jan 15, [cited 2007]. Available from: http://sowf.moi.gov.tw/english/english.htm

[32] 2007 Jan 15, [cited 2007]. Available from: http://www.moi.gov.tw/ english/SocialAffairs.asp

[33] Mills L. Killing her softly: Intimate abuse and the violence of state intervention. Harvard Law J 1999; 113: 550 .

[34] Rodriguez MA, McLoughlin E, Bauer HM, Paredes V, Grumbach $\mathrm{K}$. Mandatory reporting of intimate partner violence to police: Views of physicians in California. Am J Public Health 1999; 89: 575.

[35] Culross PL. Health Care System Responses to Children Exposed to Domestic Violence. Domestic Violence and Children, Winter 1999 [9, Issue 3. Retrieved 2003 Nov 28]. Available from: http://www. princeton.edu/futureofchildren/publications/docs/09 $03 \quad 7 . p d f$ 